\title{
Van der Waals Nanocapsular Complexes of
}

\section{Amphiphilic Calixarenes}

Gennady S. Ananchenko, ${ }^{*} \dagger$ Konstantin A. Udachin,$\dagger$ Michaela Pojarova, $\dagger$ Alix Dubes,$\dagger$ John A. Ripmeester, † Said Jebors, § Anthony W. Coleman§

National Research Council Canada, Steacie Institute for Molecular Sciences, 100 Sussex

Dr., Ottawa, K1A 0R6 Canada and Institut de Chimie et Biologie des Proteins, 7 Passage du Vercors, F-69367 Lyon Cedex 07, France

\section{SUPPORTING INFORMATION}

Complex $\mathrm{C} 4 \mathrm{OH} \cdot \mathrm{THF}$

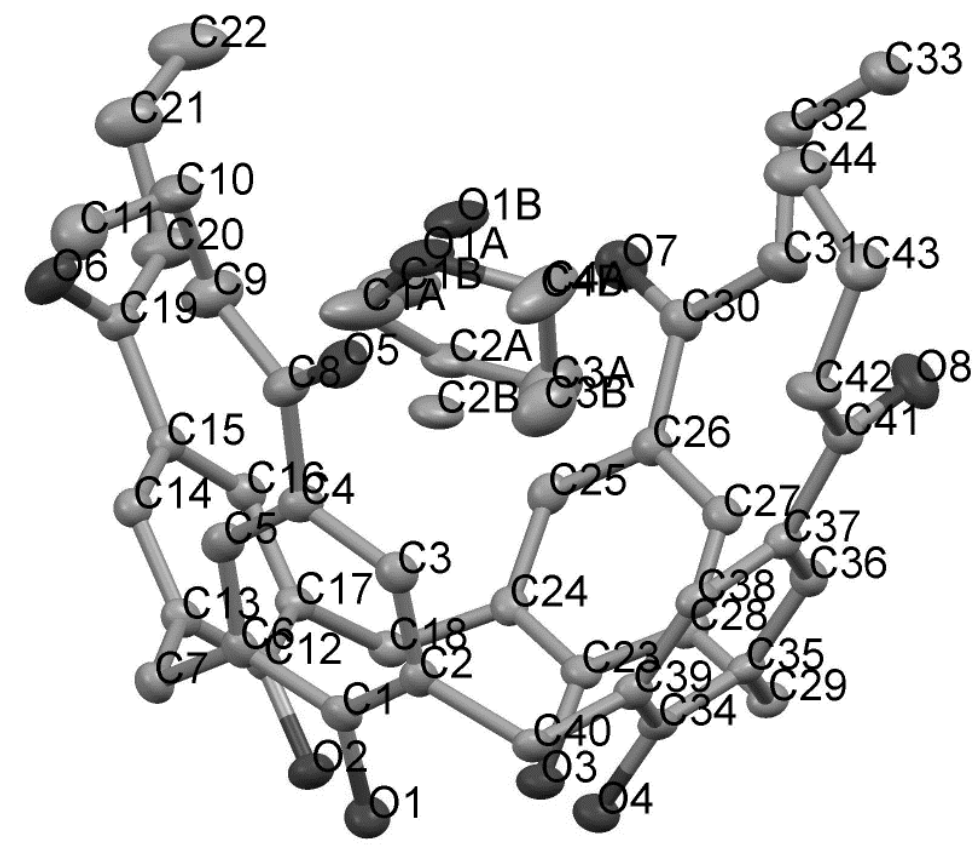




\section{Complex $\mathrm{C} 6 \mathrm{OH} \cdot 2 \mathrm{THF}$}

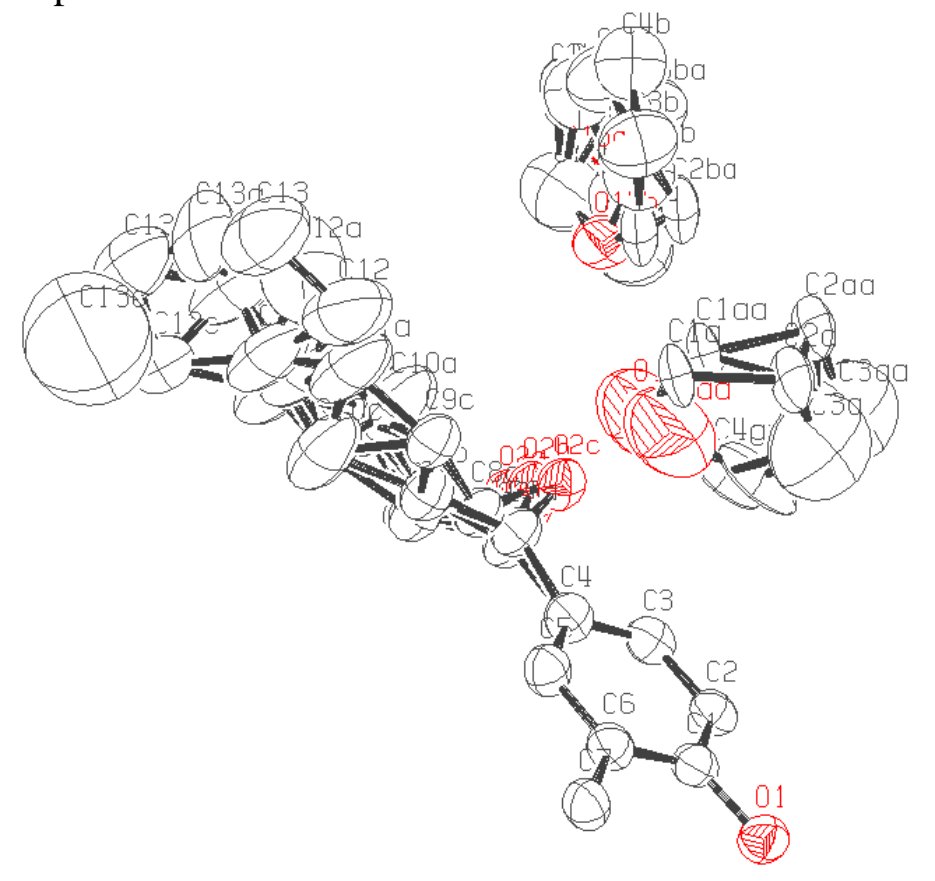

\section{Complex $\mathrm{C} 6 \mathrm{OH} \cdot \mathrm{HT} \cdot \mathrm{EtOH}$}

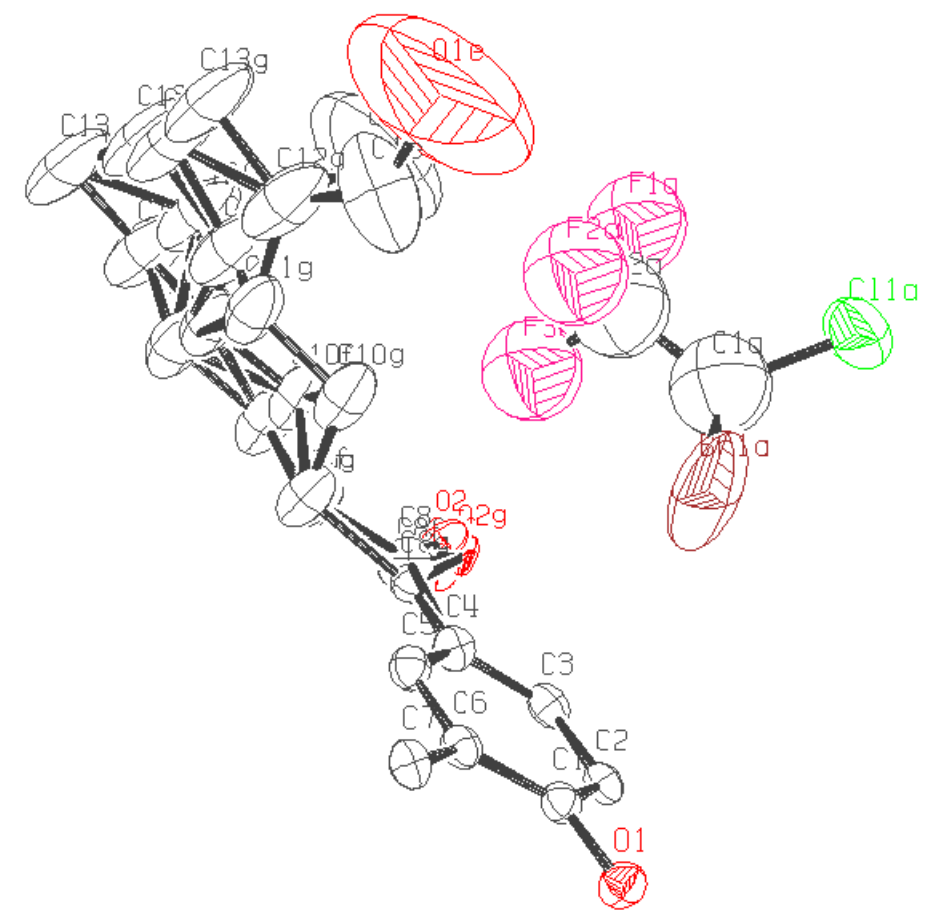


Complex C10OH·1.5Dioxane

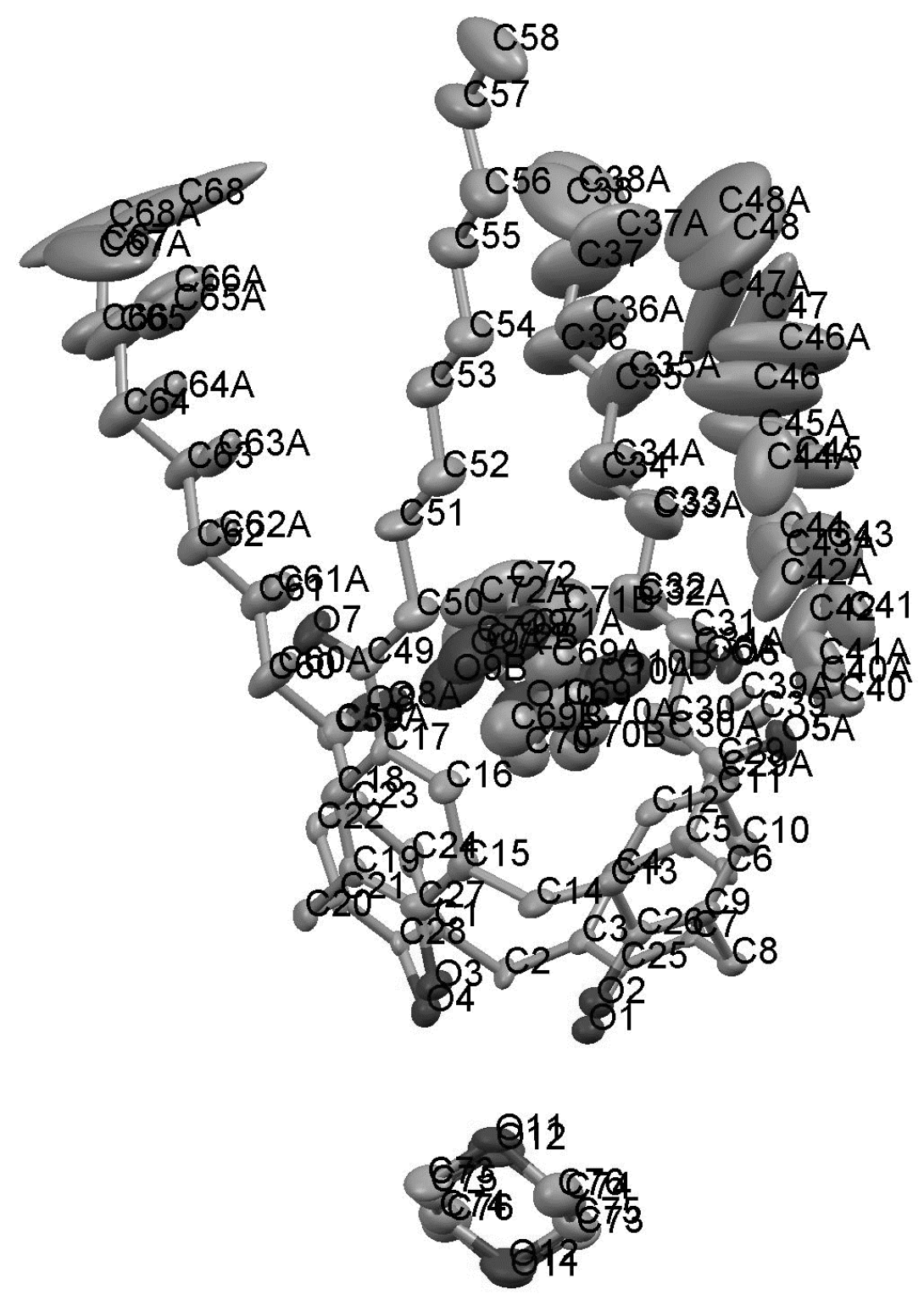

